This article was downloaded by:[University of Toronto]

On: 8 June 2007

[University of Toronto]

Access Details: [subscription number 768504461]

Publisher: Routledge

Informa Ltd Registered in England and Wales Registered Number: 1072954

Registered office: Mortimer House, 37-41 Mortimer Street, London W1T 3JH, UK

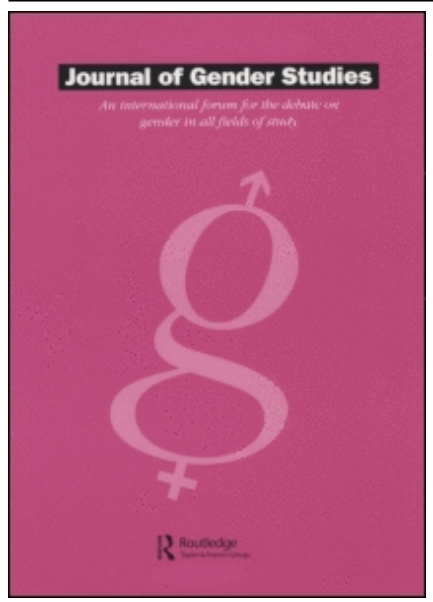

\title{
Journal of Gender Studies
}

Publication details, including instructions for authors and subscription information: http://www.informaworld.com/smpp/title content=t713431253

The Problem of Exclusion in Feminist Theory and Politics: A Metaphysical Investigation into Constructing a Category of 'Woman'

To cite this Article: Goldenberg, Maya J. , 'The Problem of Exclusion in Feminist Theory and Politics: A Metaphysical Investigation into Constructing a Category of 'Woman", Journal of Gender Studies, 16:2, 139 - 153

To link to this article: DOI: $10.1080 / 09589230701324603$

URL: http://dx.doi.org/10.1080/09589230701324603

\section{PLEASE SCROLL DOWN FOR ARTICLE}

Full terms and conditions of use: http://www.informaworld.com/terms-and-conditions-of-access.pdf

This article maybe used for research, teaching and private study purposes. Any substantial or systematic reproduction, re-distribution, re-selling, loan or sub-licensing, systematic supply or distribution in any form to anyone is expressly forbidden.

The publisher does not give any warranty express or implied or make any representation that the contents will be complete or accurate or up to date. The accuracy of any instructions, formulae and drug doses should be independently verified with primary sources. The publisher shall not be liable for any loss, actions, claims, proceedings, demand or costs or damages whatsoever or howsoever caused arising directly or indirectly in connection with or arising out of the use of this material.

(C) Taylor and Francis 2007 


\title{
The Problem of Exclusion in Feminist Theory and Politics: A Metaphysical Investigation into Constructing a Category of 'Woman'
}

\author{
MAYA J. GOLDENBERG
}

\begin{abstract}
The precondition of any feminist politics - a usable category of 'woman' - has proved to be difficult to construct, even proposed to be impossible, given the 'problem of exclusion'. This is the inevitable exclusion of at least some women, as their lives or experiences do not fit into the necessary and sufficient condition(s) that denotes group membership. In this paper, I propose that the problem of exclusion arises not because of inappropriate category membership criteria, but because of the presumption that categories can only be organised by identity relations or shared properties among their members. This criterion of sameness as well as the characterisation of this exclusion as essentialism attests to a metaphysics that is not conducive to resistance and liberatory projects. Following a strain of hybrid thinking in feminist and post-colonial theory, I outline an alternative pluralist logic that confronts oppressive binaries that impede theory work in gender, sexuality, and race theory, and limit political action and resistance. The problem of exclusion is neither irresolvable nor is it essentialism. Instead it is a denial of subjectivity due to pseudodualistic self/Other dichotomies that can be resisted by adopting a new categorial logic. While this paper focuses on the specific problem of formulating a category of 'woman', it has implications for other areas of gender, critical race, and postcolonial theory. Rather than working toward an inclusive category founded on sameness, theorists need to develop independent and positive categories grounded in difference. Our current categorial logic does not permit such a project, and therefore a new metaphysics must be adopted.
\end{abstract}

KEYWORDS: Exclusion, difference, essentialism, woman, subjectivity, other(ness)

\section{I}

The precondition of feminist theory and politics is a useable category of 'woman'. Gender is a central analytic category in feminist thought, and political action on behalf of women requires some understanding of what $i s$ a woman. Elizabeth Grosz has asked,

if women cannot be characterised in any general way, if all there is to femininity is socially produced, how can feminism be taken seriously? What justifies the

Correspondence Address: Maya J. Goldenberg, 88 College Street, Toronto, Ontario, Canada, M5G 1L4; Tel.:(416)978-2709; Email: maya.goldenberg@utoronto.ca

Journal of Gender Studies, Vol. 16, No. 2 July 2007, pp. 139-153

ISSN 0958-9236 Print/ISSN 1465-3869 $\quad$ (c) 2007 Taylor \& Francis

http://www.tandf.co.uk/journal DOI: 10.1080/09589230701324603 
assumption that women are oppressed as a sex? ... If we are not justified in taking women as a category, what political grounding does feminism have?

(Grosz, 1994, p. 93)

The project of category construction has proved to be vexing, however, as, despite best efforts, the act of categorisation seems to run up against the problem of exclusion (Spelman, 1988). Past investigations into the attribute or experience shared by all women even those taken on by well-intended non-essentialist feminists - have resulted in the exclusion of at least some women. The precondition of feminist theory and politics has thus appeared to be irresolvably contradictory, where one must create unity (a category of women) without denying difference among its members.

The problem of exclusion has been widely characterised as essentialism. Sexist constructions of women are argued to essentialise women, and feminist social constructionist counter accounts further essentialised by excluding the lived experiences of marginalised women, such as poor and working-class women, women of colour, and lesbians. Empirical research, especially cross-cultural investigations, into women's lives has revealed enormous variety in the attributes and experiences of women, and thus the contradiction has seemed irresolvable. Any attempt to construct a cohesive category of women, which has involved a reduction of the multiplicity of women's attributes and experiences into one or several shared underlying features, has excluded at least some women because they or their experiences do not fit the suggested criteria. The gravity of this exclusion led Elizabeth Spelman to charge feminist theory with reproducing the very exclusionary practices of androcentric Western philosophy that it had set out to oppose (Spelman, 1988, pp. ix, 5). The conflict of unity and difference has led some thinkers to argue that any use of 'woman' as a generalised category commits one to metaphysics and essentialism (Moi, 1985, p. 139).

The difficulty - 'the problem of exclusion' - has something to do with generalisation. Spelman's charge details the false assumptions, projections, and power relations that accompany the investigation of gender concepts. She brings attention to the fact that the act of categorising is the act of deciding what distinctions matter and is therefore itself a political act (as it reflects the interests and positions of the categoriser). Yet some level of generality about women seems to be an inescapable feature of feminism, as generalisation grants explanatory power and allows for political organisation and action. Spelman is cognisant of this, of course, and does not want to abandon feminist practices. She does, however, demand that we cease to be unreflective about the ways that we weigh the significance of differences among women in our theorising. It is this kind of unreflectiveness that allowed many feminists not to see how their attempts to isolate feminism's central concepts - gender and sexism - from other elements of identity and forms of oppression served to maintain white middle-class privilege in feminist theory (Spelman, 1988, p. 16).

In this paper, I argue that many feminists find themselves unable to successfully construct an inclusive category of women because they retain a monistic metaphysical framework. The set-theoretic account of real categories, which is grounded in Aristotelian metaphysics, in fact runs counter to the anti-essentialist ${ }^{1}$ political stance held by many feminists. Anti-essentialism is a metaphysical view and category construction is a metaphysical project, and thus feminists must address their metaphysical assumptions and commitments in their practical work and activism. The conflict of unity and difference 
described above is evidence of a futile negotiation of anti-essentialism within an Aristotelian metaphysical worldview. This framework posits categories as bounded by shared properties between members, and thus the feminist project of category construction within this metaphysical setting is necessarily a project of inclusion as sameness.

The characterisation of the problem of exclusion as essentialism attests to this untenable metaphysics for building a category of women. Aristotelian metaphysics is just one version of monologic (or monistic logic), which posits a single and unified structuring of the world that effectively denies women the opportunity to assert agency (cf. Daly, Irigaray, Lugones). This worldview should therefore be regarded as inappropriate for feminist theory and politics. Following Irigaray, I propose that theorising difference rather than sameness is required to construct an independent and positive category of 'woman'. Such an effort requires abandoning monologic in favour of polylogic or a pluralist metaphysics. Only this framework permits female subjectivity, even multiple female subjectivities, as the category of woman is no longer defined by the characteristics that demarcate unitary female subjectivity.

\section{II}

Feminist philosophy begins from the perspective of the excluded Other, and the feminist project has been, as just mentioned, a project of inclusion. Writing from a variety of perspectives, feminist philosophers challenge traditional philosophy on the grounds of producing supposedly inclusive narratives of human experience that are in fact narratives of male experience. Mainstream philosophy is argued to fail to take seriously women's interests, identities, and issues, as well as failing to recognise women's ways of being, thinking, and doing as being equally valuable as those of men. By being excluded from conceptions of knowledge, rationality, and agency, women are denied identity or subjectivity. Furthermore, women are given little intellectual room to contest these characterisations of themselves, as the sexist constructions have been cleverly masked as natural or biological, and therefore non-political (or politically motivated). Feminism thus starts with the task of providing a counter-account of women that accurately represents all women.

The exclusion that women face by patriarchal and sexist worldviews has been widely characterised as essentialism. The naturalistic accounts of women as weak, feminine, irrational, immature, uncultured, and embodied seem to posit an enduring and inescapable property or attribute shared by all women. In other words, women have been determined by their condition of womanhood, and because misogyny places negative value on these features, the oppression and second-class social status that women have endured are supposed to be largely justified.

Essentialism is the thesis that objects possess certain necessary properties. Essential properties or essences function to: (i) explain or cause an object's characteristic behaviour; (ii) classify objects into kinds; (iii) serve as the basis for the identity of things (Witt, 1995, p. 321). Given this description of essentialism, which roughly captures Aristotle's use of the term (see Metaphysics VII-IX), gender essentialism is the thesis that there is some property (or properties) necessary to me being a woman and definitive of a generic category of 'woman'. Because women's essential properties were typically framed in naturalistic terms in patriarchal discourse, essentialism and biologism have been fairly consistently equated in feminist formulations of anti-essentialism (Witt, 1995, p. 324). 
Many feminists reacted to this 'exclusion as essentialism' with social constructionism (or social constructivism), the position that women are made and not born. ${ }^{2}$ This paraphrasing of Beauvoir's (1989) famous assertion is the guiding maxim of the culturalist or constructivist critique of essentialism, which holds that femininity is a cultural construct in the service of oppressive powers of patriarchy. By promoting an essential difference of woman grounded in the body, the argument runs, essentialism plays straight into the hands of the patriarchal order, which has traditionally invoked anatomical and physiological differences to legitimate the socio-political disempowerment of women (Schor, 1994b, p. 43). This 'liberationist critique', which is maintained by a rigid sex/gender distinction, seemed to counter the exclusions invoked by sexist accounts of the essence of woman and reaffirm the possibility of women getting out of their experiences of being oppressed, unappreciated, and victimised, and then asserting themselves as agents. This project ran into problems, however, as it seemed that any attempt by feminists to offer an inclusive and non-essentialist account of women still excluded some women - notably women with very different backgrounds and life-experiences than the authors of the new nonessentialist social constructions of 'woman'. Poor and working-class women, women of colour, and lesbians were being excluded from the new narratives of 'what women are' being constructed by largely white, heterosexual, and middle-class women. Seeing that exclusion was once again occurring, second-wave feminists were accused of reessentialising women. ${ }^{3}$

Unlike other critiques of essentialism (i.e. the Lacanian linguistic critique and the Derridian regard of essentialism as being complicit with Western metaphysics and logocentrism) that focussed on the man/woman binary, this critique, launched by thirdwave feminists, emerged from within the women's movement. Essentialism, according to this critique, is a form of 'false universalism' that threatens feminist thought. 'Woman', it is argued, 'by its majestic singularity ... conspires in the denial of the very real lived differences - sexual, ethnic, racial, natural, cultural, economic, generational - that divide women from each other and from themselves' (Schor, 1994b, p. 45). By calling attention to the differences among women that are obscured in solidarity practices (whether political mobilisation or the construction of a feminist theory of the subject), this anti-essentialist critique contested the universalising that many perceived to be inextricable from philosophical investigation and political organisation.

Admitting fault, feminists have since then struggled to construct an inclusive category of women. The difficulty has been great - even proposed by many to be irresolvable - given the immense variety in the lived experiences of women, the empirical likeliness that there is no essence of women, and the feminist insistence on anti-essentialism. Feminists thus struggle to justify their retention and use of the category 'woman' for political purposes, given that they cannot seem to find that shared property that grounds the category. From this perspective, feminist politics appears to be grounded on a precarious category concept, and therefore the legitimacy of feminists' work can be argued to be in jeopardy.

\section{III}

The conflict of unity and difference in this category construction only seems irresolvable because many feminists retain a metaphysical underpinning that is not conducive to their project. Aristotelian metaphysics of substance essentialises (at least to some degree) by the very acts of generalising and category construction. Exclusion thus seems 
unavoidable, and the feminist project untenable. I am proposing that this problem is the result of an Aristotelian conception of categories that is widely accepted in theoretical discourse and this problem permeates practical projects too. When feminists choose not to 'get into' the metaphysics, we unreflectively retain this problematic viewpoint, which in fact contradicts our anti-essentialist standpoint and renders our categorial project unsustainable.

To characterise exclusion as essentialism is to implicitly accept a categorial logic that is grounded in Aristotelian metaphysics, which, interestingly, is the kind of essentialist metaphysics that feminists resist. Aristotle holds a set-theoretic conception of categories, where group membership is entailed by a property shared by all members. Many feminists retain this set-theoretic construction of categories in their unquestioning assumption that creating a category of women entails a positing of a shared property or experience possessed by all women. Spelman writes that

the logic of [feminist] inquiry and concern leads us to focus on the 'womanness' or womanhood of any or all women ... the logic ... directs me to disregard what differentiates one woman from another, to see beyond what is peculiar to a woman or to a group of women.

(Spelman, 1988, p. 3)

In fact, it is because of this criteria of sameness that the conflict of unity and difference arises, as there seems to be no one attribute or experience shared by all women. Now, one may object that feminists can retain this conception of categories yet remain antiessentialist, as there can be weaker relations of sameness than necessary and sufficient properties. This is the very move that the majority of anti-essentialist feminists have made. However, the result has been either irresolvable contradiction or the problematic nominal or strategic essentialist view. It is not merely an added feature of Aristotelian metaphysics that Aristotle saw essences as objectively real. Any use of his categories in an antiessentialist manner will seem lacking in political force or metaphysical substantiveness. This is seen in feminist critiques of nominal essentialism and identity politics, where the term 'woman' is utilised not to name a clear and distinct identity group, but instead to denote a strategic or nominal grouping formed to address a particular political problem [see, for example, Gayatri Spivak's ‘strategic essentialism' in Landry \& MacLean (1996)]. This weaker or nominal category of woman is criticised for lacking the political force needed to legitimise women's issue.

\section{IV}

My references to Aristotle might seem unusual given that feminists typically point to John Locke and not Aristotle when historically situating essentialism in philosophical discourse; I maintain, however, that feminism's difficulties stem from Aristotelian real essences and not Lockean nominal essentialism. While real essence is understood to connote the Aristotelian understanding of essence as that which is most irreducible and unchanging about a thing, nominal essence 'signifies for Locke a view of essence as merely a linguistic convenience, a classificatory fiction we need to categorise and to label' (Fuss, 1994, p. 9). Teresa De Lauretis argues that because feminists regard the constructedness of gender and the historicity of patriarchy as axiomatic, "the "essence" of 
woman that is described in the writings of many so-called [feminist] essentialists is not the real essence, in Locke's terms, but more likely a nominal one' since this is more of a utopian, idealist project than a description of existent reality (De Lauretis, 1994, p. 3).

The essentialism/nominalism distinction has already been seriously criticised in feminist thought. For starters, the distinction is hard to maintain, as 'nominal essences are often treated by post-Lockeans as if they were real essences' (Fuss, 1994, p. 100). Naomi Schor adds that it is difficult to avoid the suspicion that just as the distinction between sex and gender serves covertly to preserve the notion of a directly accessible nature-body, the distinction between nominal and real essences keeps alive the dream of an essentialism without a body, a language without a reference, or better, a referent outside of language (Schor, 1994a, p. x).

My primary concern with nominal essentialism centres around its retention of the language of essences and the structure of essentialist categories. Grosz, for example, argues that in order to engage in political struggles centred around women, one is forced to deny one's feminist principles by utilising essentialist and universalising categories (Grosz, 1994, p. 93). Because we are unable to escape 'the limitations patriarchy imposes on ... conceptual schemas and models', essentialism (and its cognates) ought to be used strategically (pp. 93-95). Yet strategic essentialism comes across to many as a less meaningful or less substantive version of essential properties and categories. This problem arises because the grounding of categories in pseudo essences, despite being antiessentialist, is still predicated on Aristotelian metaphysics. Aristotelian categories have a certain degree of explanatory power that relies on essential properties, as these properties by proposing what is essential to all group members - are the basis of identity as well as classification into kinds. Categories are therefore supposed to be metaphysically significant; they should be able to tell us something about ourselves as individual members. Instead of arguing that the explanatory power of essential categories may be no more than an ideal (which is the move that anti-essentialists should be making), nominalism allows for the criterion of 'necessary and sufficient' to be meaningful, and, unable or unwilling to find the essence of women, instead offer ersatz essentialism rather than rejecting 'essentialistthink' altogether. Thus we retain in the Aristotelian framework the by-product of essentialist metaphysics, which is the expectation that group membership is ontologically significant. Aristotelian metaphysics has situated subjectivity within social group membership. The criteria of sameness required by set-theoretic categorial logic essentialises at least to some degree, as any marking of sameness does not only describe something shared by women, but also dictates the thing that one must possess in order to be a woman.

V

To regard categories as set-theoretic is to commit oneself to an Aristotelian metaphysics and a monistic view of the world. Furthermore, the monologic operating is explicitly phallocentric. I want to demonstrate that a category of 'woman' that adequately captures and affirms women's agency and identities cannot be constructed in a framework that reduces the multiplicity evident all around us to an underlying unity. The categorial construction should therefore not be a project of inclusion founded on sameness, but rather a project of difference. ${ }^{4}$ 
Put most generally, monistic logic, or monologic, is the organisation of the world into A/not-A categories. This statement is more than a formal claim, and in fact represents a framework for understanding and interacting with the world that has significant political consequences, particularly for women. Marilyn Frye argues that the A/not-A construction is captured in the set-theoretic model of category formation, where membership entails a condition of sameness. This organisation of the world necessitates a split-separation or easy delineation between members and non-members, such that either you are part of the category or you are not (Frye, 1996, p. 1002). Furthermore, this rigid requirement makes exclusion an 'all-or-nothing' thing. The monological world should therefore be understood to be, to use Irigaray's expression, pseudodualistic, rather than genuinely dualistic, as the not-A category, unlike the $\mathbf{A}$, is not a concrete social and ontological category of members possessing a shared attribute, that is, they do not constitute a kind. The structure of binary oppositions lead to this 'infinitisation of the negative', according to Nancy Jay, where the not-A is a conglomerate of undifferentiated (yet radically different!) entities that share no more than the feature of not being an A (Jay, 1981). If, for instance, 'horse' is assigned to $\mathbf{A}$, then not-A is everything in the world that is not a horse. Notice that 'lack of horseness', while shared between members of the not-horse category, does not predict or explain very much, if anything, about its members, who range greatly from babies to apples to clouds and water faucets.

The pseudodualism should be recognised to be troubling for women in a patriarchal society, as women cannot access subjectivity within this framework. In the act of categorising, the categoriser places himself as $\mathbf{A}$. Women are relegated to the category of 'not-men' along with horses, houses, children, and cars. In the phallic economy, Frye's observation that all of the above objects, including women and children, can and have been historically spoken of as a man's 'property', cannot be understood to be a mere coincidence (Frye, 1996, p. 1000). Phallocentrism is a representational system that uses one model of subjectivity (the male, as the phallus is primary) and defines and measures all others positively or negatively against that norm.

The relegation of women to the category not-men and their measure of sameness, oneness, or identity with the masculine subject is a recognisable impediment to the feminist project of giving women a voice/identity/subjectivity, as this amounts to women being rendered as Other. I will now argue that women cannot escape Otherness and assert themselves as agents while retaining the pseudodualistic or monological and phallocentric framework. Here I am going against all monistic conceptions of women's agency, including Iris Young's account of gender as serial (Young, 1994). In her cleverly devised and well-argued paper, Young manages to resolve the conflict of unity and difference by regarding women as passively serialised by their practico-inert constraints rather than grouped by any subject-defining feature. This means of disassociating identity and gender is problematic however because it leaves the serialised members to negotiate individual identity in a patriarchal world. As a result, women will likely need to conform to white, male, and Eurocentric standards of agency and rationality (and therefore deny their differences in favour of supposed gender neutrality). I am advocating a reconstituting of women on their own terms - an untenable feat within the constraints of monologic. For example, Irigaray's model of sexual difference is a recategorisation of women by women, where women can use their own standards of identity, agency, rationality, and knowledge (Irigaray, 1993). I will argue shortly why such projects of difference (rather than sameness) require a polylogic. 
The status of women as members of the not-men category should also suggest that women have not been excluded through essentialism per se, as no one would suggest that non-manness predicts or causes the behaviours of kittens, vanilla ice-cream, telephone poles, and even women. While categorising essentialises in the Aristotelian framework, exclusion does not. The exclusion that women experience is a denial of subjectivity, while an essentialised individual or kind can still have an identity. In fact, the essence of an individual is supposed to be his or her identity. By men (more accurately, white, heterosexual, and middle class men) placing themselves as categorisers, or A-category subjects, not-men are non-subjects as they are members of a chaotic confusion rather than a set. Here we see the pseudodualism. In the social world, to be not-A is to be a non-subject, and women are excluded from agency and subjectivity not by being essentialised but by being rendered non-subjects by not fitting into an ethnocentric conception of subjectivity instituted by men who placed themselves as paradigm subjects (cf. Frye, 2000).

With subjectivity contained in (or at least closely connected to) social category membership, and the patriarchal world constructed monologically, women are irrevocably rendered as Other, and thus denied subjectivity, unless they rid themselves of this otherness. To have subjectivity, one must be a signifier, and in a patriarchal society, the phallus is the signifier. Monologic does not (logically) permit women to have identities as women. To enter language, women have to give up their sex, and these projects of gender neutralising and universal subjectivity have proven to be problematic. To be clear, poststructuralists do not regard language as a tool for communication, but rather the site or location where subject positions are constructed. In any binary structure, including the opposition that typically characterises gender relations, only one term has positive value and the second is defined as the negation of the first (i.e. by its absence of the defining attributes of the first). Thus the first (the signifier) relies on the second in order to be clearly and precisely formulated. The male subject requires the female-as-Other in order to have subjectivity. This construction implies more than the vested interest that some men will have in resisting a woman's fight for subjectivity; instead her endeavour might be fruitless. The monism that passes for a man/woman dualism in fact permits only one subject in the phallic economy. There is no allowance for two gender categories in monologic, but only the one 'man' and its negation 'not-man', and therefore an alternative metaphysics is required for the feminist project of category construction.

\section{VI}

Polylogic is the metaphysical framework that needs to be in place in order to displace the A/not-A dichotomy with a genuine plurality. I adopt the position, espoused by theorists of difference, that we need two subjectivities, $\mathbf{A}$ and $\mathbf{B}$, instead of only one and its negation, as it is the $\mathbf{B}$ category, existing in an $\mathbf{A}: \mathbf{B}$ gender relationship, that adequately captures the type of category of 'woman' that feminists should be working toward constructing. I will now demonstrate that the introduction of a second independent and self-supporting gender category (and subjectivity) requires a polylogic or pluralist worldview, as this is a positive category that is not dependent on negation (or on a condition of sameness).

To flesh out the B category, I follow Irigaray's call for a construction of 'woman' by women. Irigaray's work highlights how women have been ignored or mischaracterised in Western theoretical discourse, an exclusion that she regards to be a denial of agency advanced by the naming (describing, characterising, categorising, and even essentialising) 
of 'woman' by men. What resulted was often all-out exclusion, where women were rendered invisible by the (male) modern subject (often under the guise of supposed gender neutrality). Alternatively, women were dismissed as irrational and amoral. In some cases, women were commended, if not valorised, for being caring and peaceful while being excluded from the public sphere. Here we see that exclusion is not always all-or-nothing as 'exclusion as essentialism' suggests - but can instead be experienced in degrees of marginalisation or mischaracterisation.

In her debunking of the oppressive fiction of the universal subject, Irigaray theorises feminine specificity. What would presumably result is a category that does not render female difference (from men) as either inferior or invisible, but instead embraces women's needs, interests, bodies, and sex organs as important, legitimate, and visible. While difference is suspicious to egalitarian feminists, as defenders of patriarchy also stressed women's differences from men, theorists of sexual difference conceive of difference positively rather than negatively. Furthermore there is reason to be suspicious of the liberal form of equality through sameness (and the invisibility of difference), as women are rendered 'just like' men, but men are noticeably not regarded as 'just like' women. In this categorial reconstruction, the $\mathbf{B}$ category would be markedly different from the prior notA category that women have inhabited. Feminist resistance to phallogocentrism takes the form of a reappraisal of the maternal as a site of empowerment. Irigaray claims these counter woman-centred genealogies to be the start of an alternative female symbolic system. While the concepts used have raised the spectre of essentialism, as they have a ring of the very biologism and naturalism that social constructionists have worked to excise from feminist thought, sexual difference should not be understood as biological difference, but 'a difference of symbolisation, a different production of reference and meaning out of a particularly embodied knowledge' (De Lauretis, 1994, p. 27). We have already seen how the monological requirement for a single unified world does not allow for genuine plurality with two distinct gender categories and two distinct subjectivities. The world can only be organised by the one subject (who happens to be a man) in order to be unified. Even the positing of a female A category would entail the problem of exclusion, and unless we make the shared property of women arbitrary, we would need to ground it in some kind of essentialism. Thus the category that we are seeking requires multiplicity. Our brand of female subjectivity - the kind that cannot be reduced to unity, that is, male-centric gender-neutrality - cannot fit into this monological space and therefore requires an act of worldmaking, a framing of an alternative worldview. These acts of worldmaking permit a different kind of category of woman - a positive category founded on difference. The concept of difference, as it has been developed in contemporary feminist theory by the likes of Irigaray, Helene Cixous, and Jane Gallop, suggests a major transformation of the social and symbolic order, which, in patriarchy, is established by the universalisation of the singular (male) identity. Difference cannot be readily accommodated in a system that reduces all difference to distinction and all identity to sameness.

\section{VII}

Aristotle regarded essential properties as the basis of natural kinds, which suggests that the latter are somehow apparent in the structure of the world. This view depicts the categoriser as a disinterested viewer who neutrally receives the intrinsic perceptual qualities of nature 
devoid of human cognition or knowledge of the subject matter. The pluralist worldview presents an alternative picture of the categoriser as imposing himself onto the world - to reduce disorder and multiplicity into order and unity - by the very act of categorising. The categoriser, or the signifier, is the subject, and thus the act of categorising is not neutral or passive, but is an assertion of self as agent onto the world. Nelson Goodman argues that human interest cannot be separated from categorising. He explains that

perceiving motion ... often consists in producing it. Discovering laws involves drafting them. Recognising patterns is very much a matter of inventing and imposing them. Comprehension and creation go together.

(Goodman, 1978, p. 22; my emphasis)

The pluralist worldview proposes that the structuring of the world does not make categories apparent. Instead, we purposefully impose categorial structure onto the world. The power dynamics that go into category formation suggest that not everyone has equal opportunity to worldmake. My proposal to construct a cohesive category of 'woman' by women is a move for women to be worldmakers.

Because categories create rather than reflect the world, there is no reason to think that we must limit ourselves to a single worldview. Instead, multiple taxonomies of the real world are possible. For example, living kinds can be organised into multiple equally objective and informative taxonomies, such as morphological species, phylogenetic species, and biological species. One's research interests will affect what properties one will observe in nature - for example, an ecologist will be looking for morphological relations among species, while a biologist taxonomises living kinds based on patterns of reproductive isolation - and which organisational scheme will be most useful (Dupré, 1996). This recognition of multiplicity is the first step toward succeeding in the feminist project of constructing a new category of women, as we have seen that there is little room for women to assert themselves in the patriarchal monological universe, where women can only gain subjectivity through conscious acts of sameness or gender-neutralising. The female subjectivity - the positive $\mathbf{B}$ category - requires a new space.

\section{VIII}

One might object to pluralist constructions because multiplicity does not seem to counter the patriarchal monological world; instead plurality seems to allow for a patriarchal construction among its many alternative worldviews. This objection is certainly warranted, as the creation of alternative worldviews, while undermining monologic, does not prove patriarchal constructs to be false.

Pluralism does not propose to break down patriarchal monological worldviews, but instead creates alternative worldviews. This is not the usual philosophical device of refutation by argumentation. Worldmaking does, however, succeed at undermining monologic by creating alternative worldviews and instances of ill-fit that cannot be reduced to fit into the singular and unified world. Maria Lugones, following a recently articulated tradition of latina writers, offers mestizaje or multiplicity as one such alternative picture which is tied to resistance and liberatory possibilities. Mestizaje is the act of being 'neither/nor, but kind of both, not quite either' (Lugones, 1994, p. 459). ${ }^{5}$ Gloria Anzaldúa wrote: 
There was a muchacha who lived near my house. La gente del pueblo talked about her being una de las otras, 'of the Others'. They said that for six months she was a woman who had a vagina that bled once a month, and that for the other six months she was a man, had a penis and she peed standing up. They called her half and half, mita'y mita, neither one nor the other but a strange doubling, a deviation of nature that horrified, a work of nature inverted.

(In Lugones, 1994, p. 460)

This ambiguity threatens order given the available classification of things. By not being able to fit into the distinct categories of monologic, being mestiza is an active defiance of this logic of purity and its domination and control over possibilities, as these border-dwellers cannot be fragmented and fit into the modern (male) subject's worldview. While the monological subject controls objects and persons via exercises of split-separation - the fragmentation of the world into pure categories of member and non-member - mestizaje defies control through simultaneously asserting the impure, curdled multiple state and rejecting fragmentation into pure parts. In this play of assertion and rejection, the mestiza is unclassifiable and unmanageable. She has no pure parts to be categorised or controlled (Lugones, 1994, p. 460). This impure resistance is an act of worldmaking, an alternative presentation of culture, gender, and race that makes one unable to fit into the structures and categories of purity. Truth, according to the pluralist, is not transcendental, but constructed and imposed by the categoriser or modern subject. Mestizaje undermines the patriarchal and Eurocentric truths by acts of making oneself unable to fit into that monological construct, for example, by gender transgression, reinventing our names for things, crossing cultures, code-switching, and undermining the orderliness of social ordering (Lugones, 1994, p. 478).

As mentioned, the act of resistance is not the usual way of refuting offensive worldviews. Instead of attempting to directly discredit the monophiliac's worldview - for example, by arguing that women are made and not born, or that race categories should be abandoned - we go at the very logic that created the unsavoury constructions of gender and race in the first place. However this mestizaje alternative worldview may not convince the lover of purity to change his ways. While providing instances that do not fit into the pure unified worldview largely undermines the assumption that multiplicity can be reduced to unity, the split-separator may choose to ignore the instances of ill-fit as aberrations, as any scientist can disregard bad samples and inconsistent results without undermining his initial hypothesis. In fact, Lugones' examination of the 'lover of purity' the seeker of truth, order, and predictability in the multiplicitous universe - suggests that it may in fact be too threatening to his sense of self to acknowledge the instances of ill-fit. It is for this reason that plural world-versions may seem inadequate to many people committed to social change, as we cannot call the modern subject's insistence on purity wrong or irrational - two intellectual trump cards. Of course it is not clear that categories of right and wrong or true and false provide more than aesthetic comfort for the activist. Even these labels may not change the monophiliac's mind, as his desire for control may in fact be pathological. While 'true', 'false', 'right', and 'wrong' can be useful when we have institutions in place that regard and make these concepts legitimate, such as in an enforceable justice system, they do little as concepts to assist in political action and change. 
IX

Polylogic allows for the construction of a category of woman that does not essentialise or exclude women because it does not entail a unitary female or women's subjectivity, where social group membership, such as by one's gender, is somehow defining. While even in monologic one is logically permitted to be a member of many different and logically independent sets simultaneously - for example my audience belongs to the set of people who read the Journal of Gender Studies as well as the set of things that are partly composed of oxygen molecules - we tend to think of identity, which is constituted largely by social categories, in A/not-A terms, where being-an-A tends to be construed as what one is. And because these sets are to some extent defining in their carving up of the universe into members and non-members, it is hard to think of one individual being a member of many such categories simultaneously. This arguably goes back to Aristotle and the practice of biological taxonomy, where what one is is one's species, and each individual is of only one species (Frye, 1996, p. 1004). I have argued that the agent-affirming category of women requires the construction of a second subjectivity or a B category. The variety of women's experiences, however, has already suggested that the $\mathbf{B}$ cannot be founded on the criteria of sameness nor does it need to be as there are other categorial logics. One can think of the $\mathbf{B}$ category as being a plurality - C, D, and E categories could be constructed - as polylogic allows for many worldviews. In a positive self-supporting category not constituted by universal exclusive relations to its negation but rather by self-reliant structures of relation and differentiation, the subjectivity associated with it 'has no built-in exclusivity or closure against other identity categories, no analytically built-in hostility to multiple category memberships and subjectivities' (Frye, 1996, p. 1004). The pluralist allowance for multiple social-identity group memberships resolves the problem of exclusion when constructing a category of 'woman' because membership in the category no longer defines what a woman is or what she should be. The separation of identity and gender also resolves the problem of essentialisation through categorisation. We see that the initial contradiction now disappears. Relating identity to a social category requires a pseudodualistic conception of categories. Once simultaneous social/ontological memberships are logically permitted, one does not need to think of any one membership as defining what or who you are.

$\mathbf{X}$

An illustration of the organisation and operation of categories founded on difference is offered in Marilyn Frye's analysis of the practices of social groups - such as women's caucuses, collectives, and various other gatherings of women who often share certain distinctions such as race, ability, sexuality, or ethnicity (Frye, 1996). Even if it was sameness that drew these women together, the group is defined and functions by its internal relations and differences. Thus theory needs to catch up with praxis to recognise that social groups are not defined by sameness, but by the interrelations of participants working through their differences. Frye writes that

this has been practically, politically, historically inevitable. If women were going to be together in women-focused, women-defined, and women-defining spaces and 
enterprises, women were going to engage in many varieties of what might be called 'the practice of differences'.

(Frye, 1996, p. 1007)

Rather than 'essentialising' women, however, 'each woman and group of women acquires deepened and more complex and more fully experienced meaning/identity through the webs of likeness and contrasts built by communities and processes that are varieties of the practice of differences' (Frye, 1996, p. 1007).

\section{XI}

The seeming irresolvability of the problem of exclusion as well as the characterisation of exclusion as essentialism attest to an inappropriate metaphysics that feminists ought to abandon. The set-theoretic understanding of categories where membership is defined by sameness, or a property shared by all members, is not conducive to a category of 'woman', given the variety among us. Furthermore, the problem of exclusion that seemed to inevitably arise when categorial projects were attempted was not essentialism but rather a denial of subjectivity due to the pseudodualistic gender dichotomy. The analytic constraints of monologic do not permit women to be subjects as women. The only option for women in this pseudodualistic framework is to rid themselves of Otherness in order to access the A category. Beauvoir understood women's liberation to require leaving differences of anatomical morphology and function nameless and without significance with respect to selfhood. Gender neutrality is the necessary response to the inescapable A/not-A or self/Other dichotomy that is only pseudodualistic with respect to subjectivity. Because the brand of female subjectivity being called for cannot be reduced to unity, that is, white, heterosexual, male-centric gender neutrality, it cannot fit into this monological space and requires a framing of an alternative worldview. Polylogic allows for a construction of a category of 'woman' that does not essentialise or exclude women because it does not entail a unitary female or women's subjectivity, where membership in a particular and significant social group is somehow defining. While Beauvoir theorised difference as negativity - as otherness precluded women from transcendence - Irigaray saw difference as the joyful reappropriation of the attributes of the other. By framing difference in terms of inequality, distinction, and opposition, monologic constrains the ways in which women can define themselves. Without a different production of reference and meaning, feminism cannot escape the problem of exclusion.

\section{Acknowledgements}

This manuscript originated as a term paper for a graduate seminar in Metaphysics and Epistemology taught by Professor Marilyn Frye at Michigan State University. The themes discussed in this course on Categories greatly influenced my thinking and I would like to thank Professor Frye for her dedicated teaching, insight, and interest in my work. I would also like to acknowledge my audience at the 2003 meeting of the Canadian Women's Studies Association for helpful questions and comments on a later draft of this work. 


\section{Notes}

${ }^{1}$ While cognisant that 'essentialism' has been used in a variety of ways in feminist theory, I choose to be ambiguous about what I mean by 'anti-essentialist' at this point to bring attention to how the term is often used unreflectively in feminist thought to denote numerous theoretical and political problems. See Marilyn Frye (2000) for discussion on how the term has been used and misused in feminist thought and Schor (1994a) for some exasperated feminist responses to 'the policing of feminism by the shock troops of antiessentialism' (p. vii).

${ }^{2}$ Simone de Beauvoir argued in The Second Sex that the intellectual and behavioural differences between men and women were historically and socially constructed gender and not sex. While (bodily) sex was seen to exist and be biologically fixed, she argued that there was no inherent or essential basis for gender differences, and that they could therefore be changed. Theoretically, women and men could be the same in all the relevant intellectual activities and social roles.

${ }^{3}$ While most feminists saw their error as stemming from a failed social constructionist project, some feminists took issue with social constructionism as a method. Diane Fuss (1989), for example, argued that social constructionism was a misguided reaction to essentialism, as it 'reessentialised' women by displacing the 'natural' with the social.

${ }^{4}$ In many ways my argument will parallel the debates over equality and difference in contemporary feminist thought. However, these debates concern the relation of women and men, while my focus is on the relation of women to each other. Accounts of sexual difference have been criticised for not saying enough about difference among women and are therefore often accused of being essentialist.

5 Other figurations aimed at displacing oppressive binaries include Donna Haraway's (2000) cyborg, Homi Bhabha's (1994) hybrid subject, and Gilles Deleuze's (1985) nomad. Haraway's (2000) cyborg metaphor serves to problematise traditional notions of the self (and the many binaries complacent in its traditional formulations), while Bhabha's (1994) postcolonial subject is always split because of its ambivalent relationship to the dominant culture. The hybrid subject is similar to mestiza, although Bhabha only focuses on ethnicity and fails to take the axes of gender, sexuality, and class into account. In 'Nomad Thought', Deleuze (1985) argues that any philosophical discourse that has its origins in institutions is part of a cultural drive towards immobility and fixity. He offers nomadism as a means to mobilise or unfix cultural dynamism.

\section{References}

Aristotle (1991) Metaphysics, translated by John H. McMahon (Amherst: Prometheus Books).

Beauvoir, S. (1989) The Second Sex (New York: Vintage Books).

Bhabha, H. (1994) The Location of Culture (New York: Routledge).

De Lauretis, T. (1994) The essence of the triangle or, taking the risk of essentialism seriously: feminist theory in Italy, the US, and Britain, in: N. Schor \& E. Weed (Eds) The Essential Difference (Bloomington: Indiana University Press).

Deleuze, G. (1985) Nomad thought, in: D. Allison (Ed.) The New Nietzsche: Contemporary Styles of Interpretation (Cambridge: MIT Press).

Dupré, J. (1996) The Disorder of Things (Cambridge: Harvard University Press).

Frye, M. (1996) The necessity of differences, Signs, 21, pp. 991-1010.

Frye, M. (2000) Essentialism/ethnocentrism: the failure of the ontological cure, in: The Social Justice Group at the Centre for Advanced Feminist Studies, University of Minnesota (Eds) Is Academic Feminism Dead? Theory in Practice (New York: New York University Press).

Fuss, D. (1989) Essentially Speaking: Feminism, Nature and Difference (New York: Routledge).

Fuss, D. (1994) Reading like a feminist, in: N. Schor \& E. Weed (Eds) The Essential Difference (Bloomington: Indiana University Press).

Goodman, N. (1978) Ways of Worldmaking (Indianapolis: Hackett).

Grosz, E. (1994) Sexual difference and the problem of essentialism, in: N. Schor \& E. Weed (Eds) The Essential Difference (Bloomington: Indiana University Press).

Haraway, D. (2000) A cyborg manifesto: science, technology, and socialist-feminism in the late 20th century, in: D. Bell \& B. Kennedy (Eds) The Cybercultures Reader (London: Routledge).

Irigaray, L. (1993) An Ethics of Sexual Difference, translated by C. Burke \& G. Gill (Ithaca: Cornell University Press).

Jay, N. (1981) Gender and dichotomy, Feminist Studies, Spring, pp. 38-56. 
Landry, D. \& MacLean, G. (1996) The Spivak Reader (New York: Routledge).

Lugones, M. (1994) Purity, impurity, and separation, Signs, 19, pp. 458-479.

Moi, T. (1985) Sexual/Textual Politics: Feminist Literary Theory (New York: Methuen).

Schor, N. (1994a) Introduction, in: N. Schor \& E. Weed (Eds) The Essential Difference (Bloomington: Indiana University Press)

Schor, N. (1994b) This essentialism which is not one: coming to grips with Irigaray, in: N. Schor \& E. Weed (Eds) The Essential Difference (Bloomington: Indiana University Press).

Spelman, E. (1988) Inessential Woman: Problems of Exclusion in Feminist Thought (Boston: Beacon Press).

Witt, C. (1995) Anti-essentialism in feminist theory, Philosophical Topics, 23, pp. 321-344.

Young, I. (1994) Gender as seriality: thinking about women as a social collective, Signs, 19, pp. 713-738. 